\title{
Metalliferous Biosignatures for Deep Subsurface Microbial Activity
}

\author{
John Parnell ${ }^{1} \cdot$ Connor Brolly $^{1} \cdot$ Sam Spinks $^{1,2}$ • \\ Stephen Bowden ${ }^{1}$
}

Received: 27 August 2015 / Accepted: 1 September 2015 /

Published online: 16 September 2015

(C) The Author(s) 2015. This article is published with open access at Springerlink.com

\begin{abstract}
The interaction of microbes and metals is widely assumed to have occurred in surface or very shallow subsurface environments. However new evidence suggests that much microbial activity occurs in the deep subsurface. Fluvial, lacustrine and aeolian 'red beds' contain widespread centimetre-scale reduction spheroids in which a pale reduced spheroid in otherwise red rocks contains a metalliferous core. Most of the reduction of Fe (III) in sediments is caused by Fe (III) reducing bacteria. They have the potential to reduce a range of metals and metalloids, including $\mathrm{V}, \mathrm{Cu}, \mathrm{Mo}, \mathrm{U}$ and $\mathrm{Se}$, by substituting them for $\mathrm{Fe}$ (III) as electron acceptors, which are all elements common in reduction spheroids. The spheroidal morphology indicates that they were formed at depth, after compaction, which is consistent with a microbial formation. Given that the consequences of Fe (III) reduction have a visual expression, they are potential biosignatures during exploration of the terrestrial and extraterrestrial geological record. There is debate about the energy available from Fe (III) reduction on Mars, but the abundance of iron in Martian soils makes it one of the most valuable prospects for life there. Entrapment of the microbes themselves as fossils is possible, but a more realistic target during the exploration of Mars would be the colour contrasts reflecting selective reduction or oxidation. This can be achieved by analysing quartz grains across a reduction spheroid using Raman spectroscopy, which demonstrates its suitability for life detection in subsurface environments. Microbial action is the most suitable explanation for the formation of reduction spheroids and may act as metalliferous biosignatures for deep subsurface microbial activity.
\end{abstract}

Keywords Deep subsurface $\cdot$ Deep biosphere $\cdot$ Reduction spheroid · Iron-reducing bacteria . Metalliferous biosignature $\cdot$ Selenium $\cdot$ Raman spectroscopy

Paper presented at the $14^{\text {th }}$ European Astrobiology Conference (EANA 2014) held 13-16 October 2014 in Edinburgh, United Kingdom.

Connor Brolly

c.brolly@abdn.ac.uk

1 Department of Geology \& Petroleum Geology, University of Aberdeen, Aberdeen, UK

2 CSIRO Mineral Resources Flagship, Australian Resources Research Centre, Perth, Australia 


\section{Introduction}

The concentration and deposition of metals by microbial activity has given rise to a wide range of ore deposits (Fallick et al. 2001; Southam and Saunders 2005; Jamieson et al. 2013). In most cases, the interaction of microbes and metals is assumed to have occurred in surface or very shallow subsurface environments. However, it has become apparent that much microbial activity occurs in the deep subsurface below continents so that at about $2 \mathrm{~km}$ depth, pore fluids typically contains $10^{4}$ cells $/ \mathrm{ml}$ (Whitman et al. 1998; McMahon and Parnell 2014). Thus, the microbial concentration of metals is likely to extend to the subsurface, and offers the potential to act as a signature for subsurface microbial activity in the geological record.

One type of metalliferous deposit that is distinctly subsurface is in continental strata, the socalled 'red beds' deposits in fluvial, lacustrine and aeolian environments in which red colour is conferred from iron oxide coatings around the sand grains. In these rocks, metals are concentrated at redox boundaries between oxidised red and reduced pale-coloured rocks. The redox-sensitive metals and metalloids concentrated at these boundaries especially include $\mathrm{V}, \mathrm{Cu}, \mathrm{Mo}, \mathrm{U}$ and $\mathrm{Se}$, but a range of other elements, including tellurium, rare earth elements and platinum group elements are also enriched at such boundaries. On an aquifer scale, the boundaries form 'roll-front' deposits, where oxidizing groundwaters penetrate sandstones containing reductants (detrital organic matter, oil, hydrogen sulfide). These deposits can be large enough to mine for metals (e.g., Northrop and Goldhaber 1990; Min et al. 2005). On a much smaller scale, red beds contain widespread centimetre-scale reduction spheroids in which a pale reduced spheroid in otherwise red rocks contains a metalliferous core (e.g., Hofmann 1990), as shown in Fig. 1.
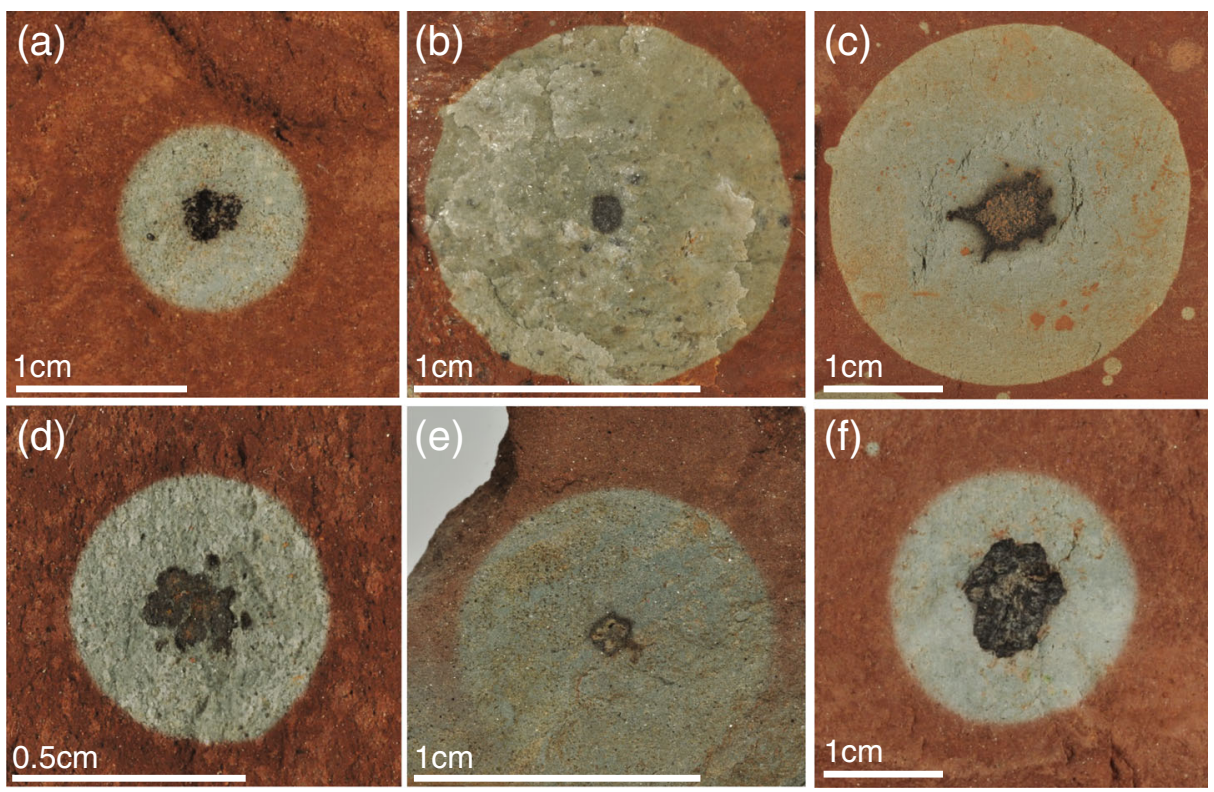

Fig. 1 Examples of $\mathrm{cm}$-scale Triassic reduction spheroids, with dark metal-rich cores. Reduced halos display almost complete sphericity. a \& f Sidmouth, Devon. b Fauld mine, Staffordshire. c Okehampton, Devon. d Bantycock mine, Nottingham 
At both scales, a microbial origin for the metal deposition has been inferred (Northrop and Goldhaber 1990; Hofmann 1991). As the host rocks are usually fully compacted, metal deposition and related microbial activity took place in the deep subsurface.

\section{The Role of Iron-Reducing Bacteria}

The defining characteristic of reduction spheroids and other reduction features in otherwise red rocks is the conversion of Fe (III) to Fe (II) mineralogy. Most of the reduction of Fe (III) in sediments is caused by Fe (III)-reducing bacteria (Lovley 1997). Where this bacterial activity is extensive, Fe (III) is reduced to Fe (II), and leached away, removing the red colouration associated with oxidised iron (Lovley 1997), and develops mottling of reduced and oxidised sediment in the subsurface. This mottling is observed in the geological record, which is thus reasoned to reflect microbial activity (Lovley et al. 1990). The widespread Geobacter metallireducens can seek out new Fe (III) oxide surfaces through chemotactic development of flagella (Childers et al. 2002), and hence colonies can exploit a volume of sediment and efficiently reduce it. The deposition of metals by reduction in the subsurface is achieved particularly through the activity of the $\mathrm{Fe}$ (III)-reducing bacteria. They have the potential to reduce a range of other metals and metalloids, including V, Cu, Mo, U and Se, by substituting them for Fe (III) as electron acceptors (Coates et al. 1996; Lovley 1997). These are all elements concentrated in red bed deposits, consistent with their purported microbial origin.

The source of the metals may be the iron oxide coatings that the bacteria strip off the sand grains. Iron oxides are major sinks for metals, liberated as labile minerals are altered during burial (Zielinski et al. 1986; Rose and Bianchi-Mosquera 1993). It is possible that the metalrich iron oxide coatings were formed with the aid of other bacteria coating the sand grains, as most subsurface bacteria reside on grain surfaces (McMahon and Parnell 2014). Once sand grains are coated with iron oxide, the coatings may engender greater bacterial loading (Lukasik et al. 1999; Bolster et al. 2001). Biofilms on sand grains in turn enhance the uptake of metals (Diels et al. 2003), so the inorganic and organic components of the grain coatings are mutually reinforcing in sequestration of metal. Experimental evidence confirms that Fe (III) reducers are effective in dissolution of trace metals in the iron oxides (Zachara et al. 2001). The concentration of metals on grain coating iron oxides is comparable to the uptake of metals on Fe (III)mineralised iron plaque around plant roots (Hansel et al. 2001), which is similarly susceptible to removal by Fe (III) reducing bacteria (Weiss et al. 2004).

Fe (III) reducing bacteria are ideally suited for subsurface growth. Many species are thermophilic, and so occur in the deep subsurface, up to several kilometres depth (Boone et al. 1995; Liu et al. 1997; Kieft et al. 1999; Holden and Feinberg 2005; Zhang et al. 2009). Experimental reduction of metals by Fe (III) reducers at $100{ }^{\circ} \mathrm{C}$ has implicated a microbial origin for uranium ore deposits (Kashefi and Lovley 2000). Fe (III) reduction is the predominant redox process in microfracture systems that are ubiquitous in the subsurface (Kinner et al. 2005). In summary, the reduction morphology, mineral and metal assemblage, and deep subsurface habitat of Fe (III) reducing bacteria all implicate their role in the formation of red bed-hosted metal deposits. Confirmatory evidence for a microbial origin for the deposition of metallic phases comes from the sulfur isotopic compositions of sulfides in the deposits. Pyrite (iron sulfide) from roll front and other red bed hosted deposits (Northrop and Goldhaber 1990; Spinks et al. 2015) and reduction 
spheroids (Spinks et al. 2010) has isotopic compositions much lighter than precursor sulfate, i.e., a degree of isotopic fractionation indicative of microbial sulfate reduction (Machel 2001).

\section{The Origin of Reduction Spheroids}

Reduction spheroids are very widely distributed in red beds, and are the most consistently encountered morphology of reduced sediment. The concentration of metals within them has been described in several case studies (e.g., Harrison 1975; Dyck and McCorkell 1983; Parnell 1988; Spinks et al. 2014). The metalliferous mineral phases are typically oxides, silicates or native elements (Harrison 1975; Hofmann 1990), rather than the sulfides that host metals in most other environments. Pyrite, which is ubiquitous in roll front deposits, is very rare in reduction spheroids. Selenides are encountered as widely as sulfides (Hofmann 1990), despite the much lower crustal abundance of selenium compared to sulfur. The spheroids have been attributed a microbial origin by Hofmann (1990, 1991) and by Spinks et al. (2010). The morphology of reduction spheroids is entirely consistent with a microbial origin. The distinctive features exhibited by spheroids are a halo of reduced iron oxide, and in some cases concentric bands enriched in metals. Bacterial colonies, including Fe (III) reducing bacteria, in plated growth media exhibit comparable haloes (Coates et al. 1998; Pham et al. 2003; Maki et al. 2012), and multiple concentric bands of growth and inhibition related to diffusion of ions from a central metallic source (Feeney et al. 1957; Matsushita et al. 1998; Lacasta et al. 1999). Reduction is also feasible through inorganic processes, but other characteristics of reduction spheroids favour a microbial origin. The spheroids developed post-compaction, not during early burial. Where reduction occurs around detrital organic matter, such as plant debris, it does not exhibit the spheroidal form, and is more likely to be lensoid, reflecting development at an early stage (as shown in Fig. 2).

The spheroidal form also indicates formation in a static pore fluid, rather than from a moving pore fluid which would lead to an asymmetric form. The spheroids are formed in host sediments with a wide range of grain sizes from mudrocks to conglomerates. This range represents a range of permeabilities and potential as aquifers, which again indicates that their formation is not dependent upon fluid flow. Instead, the spheroids must reflect a trigger for the reduction process, which in the absence of any visible nucleus is likely to be the bacteria that are both abundant and adapted to reduce metals.

Reduction haloes and associated metal concentrations are predominantly developed in continental strata, where the rocks are typically red. However, they also occur in deep marine sediments (Thomson et al. 1989, 1994), and in crystalline basement rocks (Hofmann 1990).

Fig. 2 Reduction around plant roots in Triassic siltstone. Reduction follows the morphology of reductant and therefore is elongate
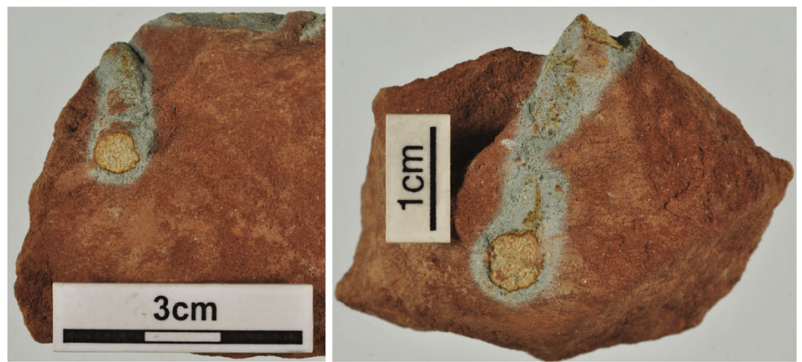
These occurrences further suggests that it is the nature of the reductant, inferred to be the ubiquitous Fe (III) reducing bacteria, rather than an aspect of the environment, that is responsible for their formation.

Where they are associated, Fe (III) reducing bacteria may competitively exclude sulfate reducers (Chapelle and Lovley 1992), which may explain why sulfides rarely occur in reduction spheroids. However, Fe (III) reducers can sequester selenium (Klonowska et al. 2005; Pearce et al. 2009), and precipitate it as selenides, consistent with their occurrence instead of sulfides. Selenium may be co-precipitated with Fe (III) oxides (e.g., Howard 1977; Cabral et al. 2012), so on microbial reduction of the oxides both iron and selenium are liberated and the selenium is readily available for concentration and reprecipitation. Although selenium forms selenide anions, it behaves like a metal and is reduced by Fe (III) reducing bacteria along with other metals. Metalliferous cores in spheroids commonly show zonation of metals, in which selenides are concentrated towards the centre. The example in Fig. 3 shows zones rich in selenium, vanadium and uranium, all of which are precipitated by Fe (III) reducing bacteria (Holmes et al. 2002; Carpentier et al. 2003; Klonowska et al. 2005).

There is a consistency in composition of metallic cores for a locality or region, such as the silver-rich cores in Devon (Harrison 1975), and the uranium-rich cores in Nova Scotia (Dyck and McCorkell 1983). This indicates that pore fluids had homogenised at a local/regional scale, which requires some movement of the fluid through the rock prior to spheroid development. The reduction spheroids then developed within the context of the homogenised fluid. Metal precipitates in the spheroid cores may just involve a redistribution of metal within the volume of the spheroid, triggered by the reduction process. However, the metals precipitated do represent enrichment over a much wider body of rock, and thereby individual spheroid chemistries can be a pathfinder to regional metal anomalies.

\section{Potential Biosignatures on Earth and Mars}

Given that the consequences of Fe (III) reduction have a visual expression, they are a potential biosignature during exploration of the terrestrial geological record. Fe (III) reducers are likely to be among the earliest widespread microbial inhabitants of Earth (Vargas et al. 1998; Kashefi and Lovley 2000). Reduction spheroids have a record back to the Mesoproterozoic (Tanton 1948; Dawes 1997; Spinks et al. 2010), so are a valuable record of microbial activity at a time when evidence for life is limited. They also show that the deep subsurface has been a habitat since early in the history of life. This early occurrence is constrained by the evolution of red beds due to increasing atmospheric oxygenation at the end of the Archean (Eriksson and Cheney 1992). Fe (III) reducing bacteria are also a potential life form (Liu et al. 1997), and the mineralogical expressions of bacterial Fe (III) reduction and Fe (II) oxidation are proposed as potential biosignatures, on other planets including Mars (Holden and Feinberg 2005; Weber et al. 2012). There is debate about the possible energy available from Fe (III) reduction on Mars (Nixon et al. 2012, 2013), but the abundance of iron in Martian soils makes it one of the most valuable prospects for life there. Entrapment of the microbes themselves as fossils is possible (Leveille and Lui 2009; Williams and Sumner 2013), but a more realistic target during the exploration of Mars would be the colour contrasts reflecting selective reduction or oxidation. It is distinctly possible that subsurface life on other rocky planets may be predominantly located in the subsurface, where there is protection 

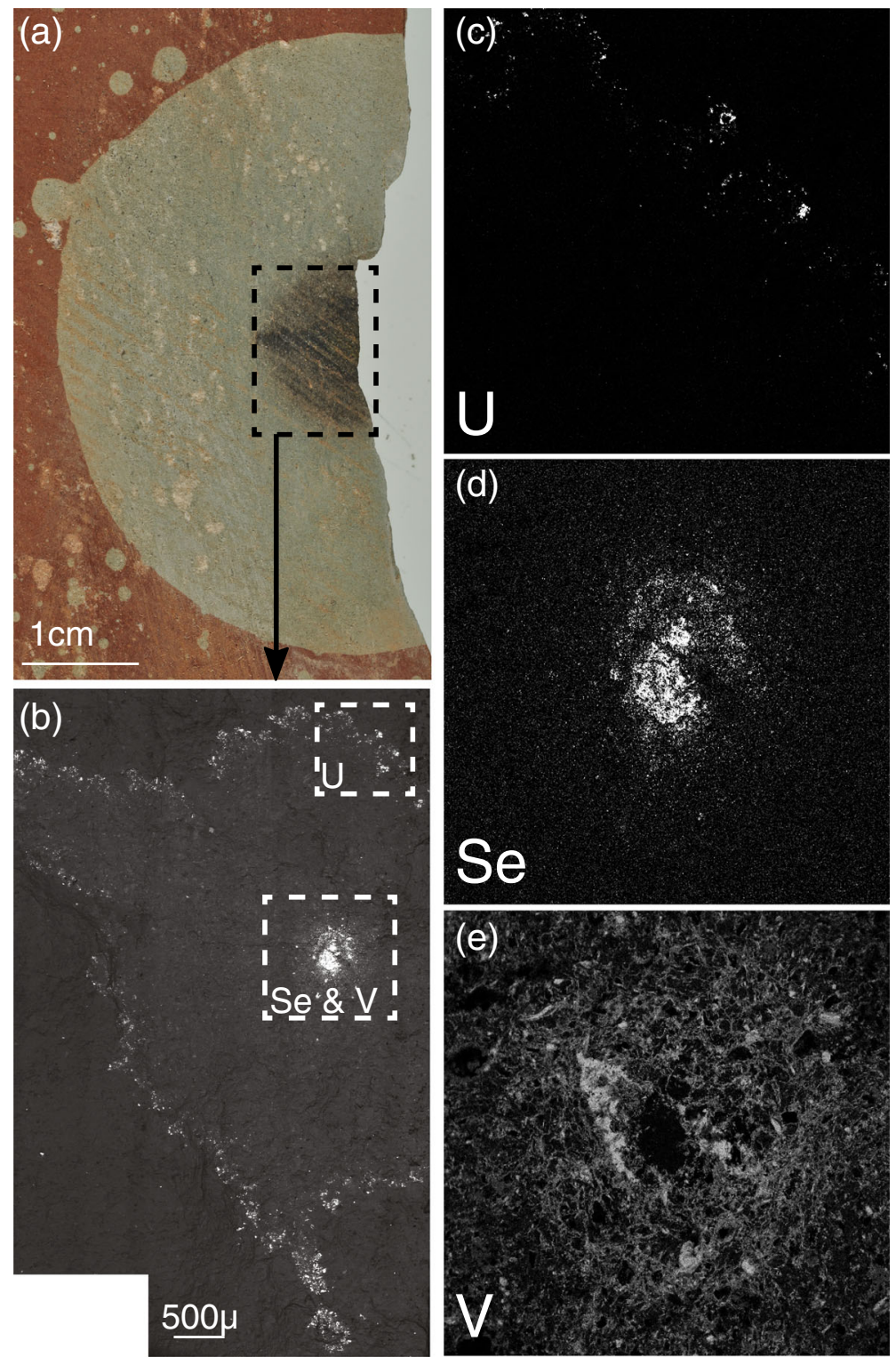

Fig. 3 a Permian reduction spheroid from Exmouth, Devon with a dark metalliferous core. b Scanning electron microscope (SEM) photomontage of the metal rich core using back-scatter electron analysis. Bright areas represent elements with high atomic numbers. c Uranium (U) element map from outer ring of core. d Selenium (Se) element map from central core. e Vanadium (V) element map from central core. Bright areas represent higher concentrations of elements, and dark areas represent low concentrations. Element maps show marked concentrations of each element

from damaging irradiation and there is not the requirement of liquid surface water (McMahon et al. 2013). If that is so, then indicators of possible subsurface life such as reduction features may be a valuable target for exploration. 
The oxidation of iron on the Martian surface is a conspicuous feature, and has been directly encountered by MER Opportunity at Meridiani Planum (Hurowitz et al. 2010) and MSL Curiosity (Blake et al. 2013) at Gale Crater, and more widely at Gale Crater by CRISM (Fraeman et al. 2013). Modelling of the evolution of sedimentary rocks at Gale Crater predicts iron oxide precipitation from the reaction of brines with country rock detritus (Bridges et al. 2013). The Gale Crater sedimentary rocks also include near-pure sulfates. Metalliferous terrestrial red beds also commonly contain sulfate and iron oxide associations, and similarly are believed to evolve through the reaction of brines with sedimentary detritus (Holmes et al. 1983). There are therefore important parallels between what is observed at Gale Crater and the settings where metalliferous biosignatures occur on Earth.

\section{Remote Analysis}

Reduction features and associated metalliferous concentrations could be analysed by several techniques during remote exploration, including on Mars. The variations in colour related to the different mineralogy of iron in reduced and oxidised states mean that the features can be detected optically. Confirmation of the contrast in iron mineralogy can be achieved using instruments adapted for Martian missions, including Mössbauer spectroscopy (Dyar and Schaefer 2004), Raman spectroscopy (Pérez and Martinez-Frias 2006) and X-ray diffraction (Bish et al. 2013). The potential for Mössbauer measurements to record microbially-induced changes in iron oxidation state was emphasized by Schröder et al. (2006), using terrestrial deep sea samples, but is equally applicable to the detection of life in subsurface environments as proposed here.

\section{The Detection of Reduction Spheroids by Raman Spectroscopy}

Raman spectroscopy has a wavelength range which covers most vibrational modes including metal oxides, carbonates, silicates and sulphates (i.e., most rock-forming minerals), therefore amongst its other many attributes, it can be used for petrographic analysis (Haskin et al. 1997; Wang et al. 1998). As previously discussed, the main factor controlling the colour contrast between the reduced halo of a reduction spot and the surrounding red rock, is the iron oxide coating on grain surfaces. Therefore a suitable target would be to analyse quartz grains across the redox boundary of a reduction spot. This can be achieved using Raman spectroscopy as it is sensitive to both quartz and hematite (De Faria et al. 1997; Ling et al. 2009). This could be applied to future landers which have spatial mapping capabilities, such as the NASA 2020 Raman instrument, SHERLOC (Beegle et al. 2015).

\section{Instrument Configuration}

Raman spectra were obtained using a Renishaw InVia H36031 confocal Raman microscope operating at a wavelength of $514.5 \mathrm{~nm}$ green monochromatic laser light. A $50 \times$ objective lens was used giving a laser "footprint" of 1-3 $\mu$ based on Beyssac et al. (2002). 10 s exposure time and 1 accumulation were used for each spectrum, giving a good signal to noise ratio with an extended spectral range of $100-2000 \mathrm{~cm}^{-1}$. A point analysis method was used, which transected a reduction spot from oxidised to reduced, back to oxidised areas. Representative spectra ( 3 from each oxidised and 4 from the reduced halo) were processed using a smooth, 
baseline subtraction and peak fit functions. This deconvolution process was repeated 3 times for each spectrum to account for human errors associated with manual baseline subtraction.

\section{Sample Collection \& Preparation}

A Permian oxidised siltstone from Budleigh Salterton, Devon, England was used with minimal sample preparation to simulate the ability of a rover during a remote mission. Therefore the sample was not cut or polished, and only reduction spots on natural bedding surfaces were analysed. The centimeter-scale size of the spots was appropriate for detection by a rover.

\section{Results and Interpretations}

Figure 4a shows a reduction spot from an oxidised siltstone from Budleigh Salterton with transect line A-B. Representative Raman spectra acquired across transect line A-B are displayed in Fig. 4b.

The main spectral bands observed are 198, 412, 462 and $1320 \mathrm{~cm}^{-1}$. Bands 198 and $462 \mathrm{~cm}^{-1}$ can be attributed to the quartz matrix. Bands at $\sim 412$ and $1320 \mathrm{~cm}^{-1}$ can be attributed to the hematite matrix. Therefore spectra from oxidised areas show a combination of bands attributed to hematite and quartz, as expected. Spectra which were acquired more proximal to the redox boundary display a reduction in band intensity for bands 412 and $1320 \mathrm{~cm}^{-1}$ (hematite), and an increase in band intensity of $462 \mathrm{~cm}^{-1}$ (quartz), which indicate that there is a reduction in hematite abundance. Spectra from within the reduction halo display major reduction in hematite band intensities, and a further increase in $462 \mathrm{~cm}^{-1}$ intensity, suggesting that the majority of the hematite has been removed by microbial action. Spectra acquired from the second oxidised portion show spectra similar to the first oxidised area and have a combination of spectra bands attributed to both hematite and quartz. This reduction feature is therefore adequately represented by the gradational disappearance and reappearance of the hematite bands observed in this Raman transect.

\section{Conclusion}

Reduction spheroids are the most consistently encountered morphology of reduced sediment. Their formation is debated; however a microbial origin is the most likely. The spheroidal morphology indicates that they formed at depth, after compaction, which reflects the interaction of metals and microbes in the deep subsurface. Reduction spheroids can therefore be used as signature of life in the terrestrial geological record, but also can be applied to life on other planets. If life on other planets is predominantly subsurface, the reduction features may be a suitable biosignature to detect it. Due to the abundance of iron on Mars, it is a suitable target for putative microbial life which utilizes iron as an energy source. Detecting signatures of microbial iron reduction, such as reduction spheroids on Mars can be achieved by many techniques, including Raman spectroscopy. Point analysis transecting a reduction spot shows a clear difference between oxidised and reduced areas. Oxidised areas show a combination of spectral bands associated with quartz and hematite. Reduced areas show a weak or no hematite signal. This shows that Raman spectroscopy is able to detect the mineralogical changes associated with microbial iron reduction. It is not direct life detection, but is a valuable strategy to help find life and further promotes the application of Raman spectroscopy for remote missions to Mars. 
Fig. 4 Raman spectroscopic transect of a reduction spheroid. a mm-scale Permian reduction spot from Budleigh Salterton, Devon with transect line A-B. b Representative spectra acquired by point analysis by Raman spectroscopy across transect line A-B. The $x$ axis is Raman shift, in reciprocal centimeters (cm-1) and the $y$-axis is Raman intensity, in arbitrary units (a.u.). Highlighted by the dashed line is the main spectral band for quartz and hematite. Spectra from the reduced areas show a weak or no hematite bands
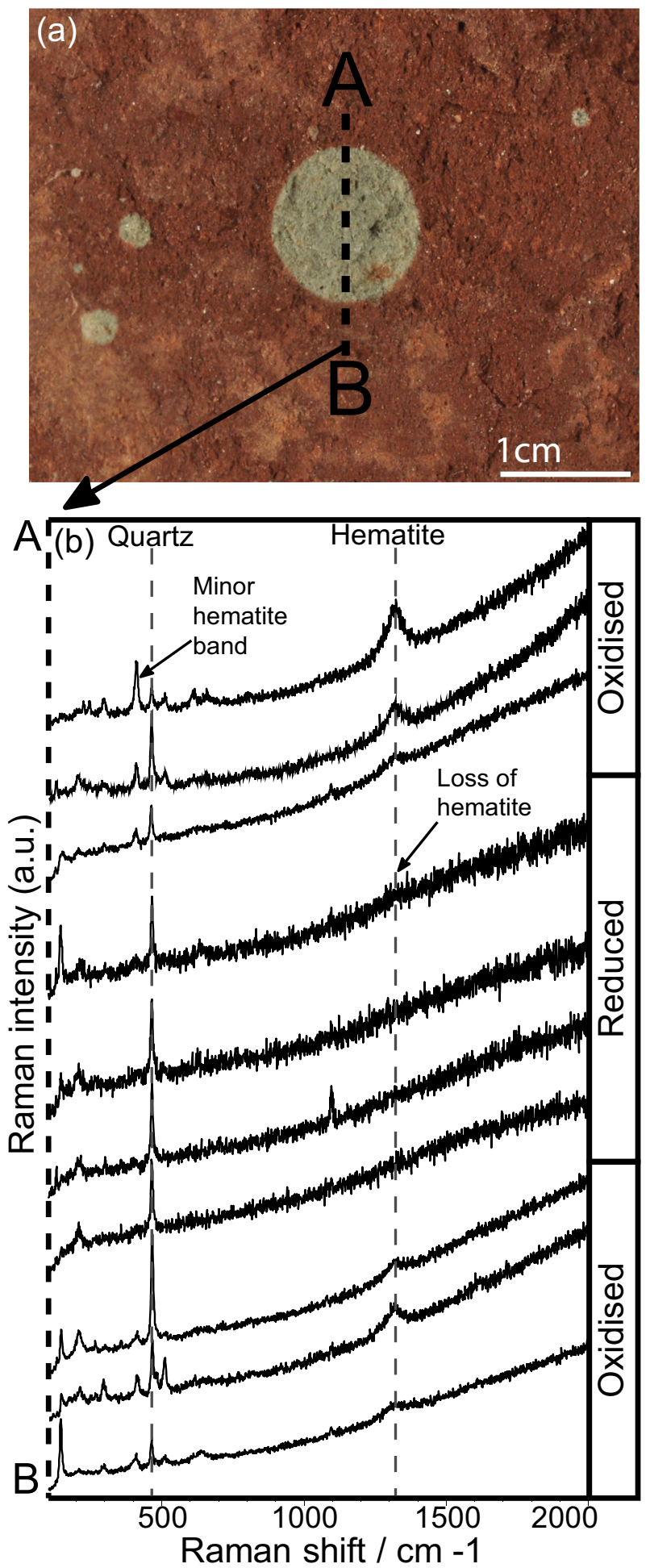
Acknowledgments We thank the British Geological Survey (BGS) for the provision of samples and the Science \& Technology Facilities Council (STFC) grant (ST/L001233/1) for $\mathrm{PhD}$ funding which aided this project. Research on selenium in reduction spheroids was also supported by NERC grants (NE/L001764/1 and NE/ M010953/1). The University of Aberdeen Raman facility was funded by the BBSRC. We also thank John Still for invaluable technical assistance.

Open Access This article is distributed under the terms of the Creative Commons Attribution 4.0 International License (http://creativecommons.org/licenses/by/4.0/), which permits unrestricted use, distribution, and reproduction in any medium, provided you give appropriate credit to the original author(s) and the source, provide a link to the Creative Commons license, and indicate if changes were made.

\section{References}

Beegle L, Bhartia R, White M, Deflores L, Abbey W, Yen-Hung W, Cameron B, Moore J, Fries M, Burton A, Edgett KS, Ravine MA, Hug W, Reid R, Nelson T, Clegg S, Wiens R, Asher S, Sobron P (2015) SHERLOC: scanning habitable environments with raman \& luminescence for organics \& chemicals. Aerosp Conf 2015:1-11

Beyssac O, Goffe B, Chopin C, Rouzaud JN (2002) Raman spectra of carbonaceous material in metasediments: a new geothermometer. J Metamorph Geol 20(9):859-871

Bish DL, Blake DF, Vaniman DT, Chipera SJ, Morris RV, Ming DW, Treiman AH, Sarrazin P, Morrison SM, Downs RT, Achilles CN, Yen AS, Bristow TF, Crisp JA, Morookian JM, Farmer JD, Rampe EB, Stolper EM, Spanovich N, Science Team MSL (2013) X-ray diffraction results from Mars science laboratory: mineralogy of rocknest at Gale Crater. Science 341:1238932

Blake DF et al (2013) Curiosity at Gale Crater, Mars: characterization and analysis of the rocknest sand shadow. Science 341:1239505

Bolster CH, Mills AL, Hornberger GM, Herman JS (2001) Effect of surface coatings, grain size, and ionic strength on the maximum attainable coverage of bacteria on sand surfaces. J Contam Hydrol 50:287-305

Boone DR, Liu Y, Zhao ZJ, Balkwill DL, Drake GR, Stevens TO, Aldrich HC (1995) Bacillus infernus sp. nov., an Fe (III)- and Mn (IV)-reducing anaerobe from the deep terrestrial subsurface. Int J Syst Bacteriol 45:441-448

Bridges JC, Schwenzer SP, Berger G, Mangold N, Wiens RC, Westall FW, Oehler DZ, Leveille R, The MSL Team (2013) Modelling fluids associated with sulfate veining in Yellowknife bay, Gale Crater. European Planetary Science Congress Abstracts, 8, EPSC2013-502

Cabral AR, Koglin N, Brätz H (2012) Gold-bearing ferroselite ( $\left.\mathrm{FeSe}_{2}\right)$ from Trogtal, Harz, Germany, and significance of its $\mathrm{Co} / \mathrm{Ni}$ ratio. J Geosci 57:265-272

Carpentier W, Sandra K, De Smet I, Brigé A, De Smet L, Van Beeumen J (2003) Microbial reduction and precipitation of vanadium by Shewanella oneidensis. Appl Environ Microbiol 69:3636-3639

Chapelle FH, Lovley DR (1992) Competitive exclusion of sulfate reduction by Fe (III)-reducing bacteria: a mechanism for producing discrete zones of high-iron ground water. Ground Water 30:29-36

Childers SE, Ciufo S, Loveley DR (2002) Geobacter metallireducens accesses insoluble Fe (III) oxide by chemotaxis. Nature 416:767-769

Coates JD, Phillips EJP, Lonergan DJ, Jenter H, Lovley DR (1996) Isolation of Geobacter species from diverse sedimentary environments. Appl Environ Microbiol 62:1531-1536

Coates JD, Ellis DJ, Blunt-Harris EL, Gaw CV, Roden EE, Lovley DR (1998) Recovery of humic-reducing bacteria from a diversity of environments. Appl Environ Microbiol 64:1504-1509

Dawes PR (1997) The proterozoic thule supergroup, Greenland and Canada: history, lithostratigraphy and development. Geology of Greenland Survey Bulletin, 174

De Faria DLA, Silva SV, De Oliveira MT (1997) Raman microspectroscopy of some iron oxides and oxyhydroxides. J Raman Spectrosc 28:873-878

Diels L, Spaans PH, van Roy S, Hooyberghs L, Ryngaert A, Wouters H, Walter E, Winters J, Macaskie L, Finlay J, Pernfuss B, Woebking H, Pümpel T, Tsezos M (2003) Heavy metals removal by sand filters inoculated with metal sorbing and precipitating bacteria. Hydrometallurgy 71:235-241

Dyar MD, Schaefer MW (2004) Mössbauer spectroscopy on the surface of Mars: constraints and expectations. Earth Planet Sci Lett 218:243-259

Dyck W, McCorkell RH (1983) A study of uranium-rich reduction spheroids in sandstones from Pugwash Harbour, Nova Scotia, Canada. Can J Earth Sci 20:1738-1746

Eriksson PG, Cheney ES (1992) Evidence for the transition to an oxygen-rich atmosphere during the evolution of red beds in the lower Proterozoic sequences of southern Africa. Precambrian Res 54:257-269 
Fallick AE, Ashton JH, Boyce AJ, Ellam RM, Russell MJ (2001) Bacteria were responsible for the magnitude of the world-class hydrothermal base metal sulfide orebody at Navan, Ireland. Econ Geol 96:885-890

Feeney RE, Petersen IM, Sahinkaya H (1957) "Liesegang-like" rings of growth and inhibition of bacteria in agar caused by metal ions and chelating agents. J Bacteriol 73:284-290

Fraeman AA, Arvidson RE, Catalano JG, Grotzinger JP, Morris RV, Murchie SL, Stack KM, Humm DC, McGovern JA, Seelos FP, Seelos KD, Viviano CE (2013) A hematite-bearing layer in Gale Crater, Mars: mapping and implications for past aqueous conditions. Geology 41:1103-1106

Hansel CM, Fendorf S, Sutton S, Newville M (2001) Characterisation of Fe plaque and associated metals on the roots of mine-waste impacted aquatic plants. Environ Sci Technol 35:3863-3868

Harrison RK (1975) Concretionary concentrations of the rarer elements in Permo-Triassic red beds of south-west England. Geol Surv Great Brit Bull 52:1-26

Haskin LA, Wang A, Rockow KM, Jolliff BL, Korotev RL, Viskupic KM (1997) Raman spectroscopy for mineral identification and quantification for in situ planetary surface analysis : a point count method. J Geophys Res 102:19293-19306

Hofmann BA (1990) Reduction spheroids from northern Switzerland: mineralogy, geochemistry and genetic models. Chem Geol 81:55-81

Hofmann BA (1991) Mineralogy and geochemistry of reduction spheroids in red beds. Mineral Petrol 44:107124

Holden JF, Feinberg LF (2005) Microbial iron respiration near $100^{\circ} \mathrm{C}$. In: Hoover RB, Levin GV, Rozanov AY, Gladstone GR (eds) Astrobiology and planetary missions. Proceedings SPIE, 5906, pp 57-67

Holmes I, Chambers AD, Ixer RA, Turner P, Vaughan DJ (1983) Diagenetic processes and the mineralization in the Triassic of central England. Mineral Deposita 18:365-377

Holmes DE, Finneran KT, O’Neil RA, Lovley DR (2002) Enrichment of Geobacteraceae associated with stimulation of dissimilatory metal reduction in uranium-contaminated aquifer sediments. Appl Environ Microbiol 68:2300-2306

Howard JH (1977) Geochemistry of selenium: formation of ferroselite and selenium behaviour in the vicinity of oxidizing sulphide and uranium deposits. Geochim Cosmochim Acta 41:1665-1678

Hurowitz JA, Fischer WW, Tosca NJ, Milliken RE (2010) Origin of acidic surface waters and the evolution of atmospheric chemistry on early Mars. Nat Geosci 3:323-326

Jamieson JW, Wing BA, Farquhar J, Hannington MD (2013) Neoarchaean seawater sulphate concentrations from sulphur isotopes in massive sulphide ore. Nat Geosci 6:61-64

Kashefi K, Lovley DR (2000) Reduction of Fe (III), Mn (IV), and toxic metals at $100^{\circ} \mathrm{C}$ by Pyrobaculum islandicum. Appl Environ Microbiol 66:1050-1156

Kieft TL, Fredrickon JK, Onstott TC, Gorby YA, Kostandarithes HM, Bailey TJ, Kennedy DW, Li SW, Plymale AE, Spadoni CM, Gray MS (1999) Dissimilatory reduction of Fe (III) and other electron acceptors by a thermus isolate. Appl Environ Microbiol 65:1214-1221

Kinner NE, Eighmy TT, Mills M, Coulburn J, Tisa L (2005) Microbial processes in fractured rock environments. In: Faybishenko B, Witherspoon PA, Gale J (eds) Dynamics of fluids and transport in fractured rock, vol 162. Geophysical Monograph Series, pp 183-193

Klonowska A, Heulin T, Vermeglio A (2005) Selenite and tellurite reduction by Shewanella oneidensis. Appl Environ Microbiol 71:5607-5609

Lacasta AM, Cantalapiedra IR, Auguet CE, Peñaranda A, Ramírez-Piscina L (1999) Modelling of spatiotemporal patterns in bacterial colonies. Phys Rev E 59:7036-7041

Leveille RJ, Lui S (2009) Fossilization of iron-oxidizing bacteria at hydrothermal vents: a useful biosignature on Mars? American Geophysical Union, Spring Meeting 2009, abstract \#B13B-07

Ling ZC, Wang A, Jolliff BL, Li C, Liu J, Bian W, Ren X, Mu L, Su Y (2009) Raman spectroscopic study of quartz in lunar soils from Apollo 14 and 15 missions. In 40th Lunar and Planetary Science Conference, Abstract 1823, 6-7

Liu SV, Zhou J, Zhang C, Cole DR, Gajdarziska-Josifovska M, Phelps TJ (1997) Thermophilic Fe (III)-reducing bacteria from the deep subsurface; the evolutionary implications. Science 277:1106-1109

Lovley DR (1997) Microbial Fe (III) reduction in subsurface environments. FEMS Microbiol Rev 20:305-313

Lovley DR, Chapelle FH, Phillips EJP (1990) Fe (III)-reducing bacteria in deeply buried sediments of the atlantic coastal plain. Geology 18:954-957

Lukasik J, Cheng Y-F, Lu F, Tamplin M, Farrah SR (1999) Removal of microorganisms from water by columns containing sand coated with ferric and aluminium hydroxides. Water Res 33:769-777

Machel HG (2001) Bacterial and thermochemical sulphate reduction in diagenetic settings - old and new insights. Sediment Geol 140:143-175

Maki ML, Idrees A, Leung KT, Qin W (2012) Newly isolated and characterized bacteria with great application potential for decomposition of lignocellulosic biomass. J Mol Microbiol Biotechnol 22:156-166 
Matsushita M, Wakita J, Itoh H, Ràfols I, Matsuyama T, Sakaguchi H, Mimura M (1998) Interface growth and pattern formation in bacterial colonies. Phys A 249:517-524

McMahon S, Parnell J (2014) Weighing the deep continental biosphere. FEMS Microbiol Ecol 87:113-120

McMahon S, O’Malley-James J, Parnell J (2013) Circumstellar habitable zones for deep terrestrial biospheres. Planet Space Sci 85:312-318

Min M, Xu H, Chen J, Fayek M (2005) Evidence of uranium biomineralization in sandstone-hosted roll-front uranium deposits, northwestern China. Ore Geol Rev 26:198-206

Nixon SL, Cockell CS, Tranter M (2012) Limitations to a microbial iron cycle on Mars. Planet Space Sci 72:116128

Nixon SL, Cousins CR, Cockell CS (2013) Plausible microbial metabolisms on Mars. Astron Geophys 54:1.131.16

Northrop HR, Goldhaber MB (1990) Genesis of the tabular-type vanadium-uranium deposits of the Henry basin, Utah. Econ Geol 85:215-269

Parnell J (1988) Red bed uranium-vanadium mineralization in the Permo-Triassic of Belfast. Irish J Earth Sci 9: 119-124

Pearce CI, Pattrick RAD, Law N, Charnock JM, Coker VS, Fellowes JW, Oremland RS, Lloyd JR (2009) Investigating different mechanisms for biogenic selenite transformations: Geobacter sulfurreducens, Shewanella oneidensis and Veillonella atypica. Environ Technol 30:1313-1326

Pérez FR, Martinez-Frias J (2006) Raman spectroscopy goes to Mars. Spectrosc Eur 18:18-21

Pham CA, Jung SJ, Phung NT, Lee J, Chang IS, Kim BH, Yi H, Chun J (2003) A novel electrochemically active and Fe (III)-reducing bacterium phylogenetically related to Aeromonas hydrophilia, isolated from a microbial fuel cell. FEMS Microbiol Lett 223:129-134

Rose AW, Bianchi-Mosquera GC (1993) Adsorption of Cu, Pb, Zn, Co, Ni, and Ag on goethite and hematite: a control on metal mobilization from red beds into stratiform copper deposits. Econ Geol 88:1226-1236

Schröder C, Bailey B, Klingelhöfer G, Staudigel H (2006) Fe Mössbauer spectroscopy as a tool in astrobiology. Planet Space Sci 54:1622-1634

Southam G, Saunders JA (2005) The geomicrobiology of ore deposits. Econ Geol 100:1067-1084

Spinks SC, Parnell J, Bowden SA (2010) Reduction spots in the Mesoproterozoic age: implications for life in the early terrestrial record. Int J Astrobiol 9:209-216

Spinks SC, Parnell J, Still JW (2014) Redox-controlled selenide mineralization in the upper old red sandstone. Scott J Geol 50:173-182

Spinks SC, Parnell J, Bellis J, Still J (2015) Remobilization and mineralization of selenium-tellurium in metamorphosed red beds: evidence from the Munster Basin, Ireland. Ore Geology Reviews (in press)

Tanton TL (1948) Radioactive nodules in sediments of the Sibley Series, Nipigon, Ontario. Trans R Soc Can 42: 69-75

Thomson J, Higgs NC, Colley S (1989) A geochemical investigation of reduction haloes developed under turbidites in brown clay. Mar Geol 89:315-330

Thomson J, Rothwell RG, Higgs NC (1994) Development of reduction haloes under calcareous and volcaniclastic turbidites in the Lau Basin (southwest Pacific). Proc Ocean Drill Program Sci Results 135: $151-162$

Vargas M, Kashefi K, Blunt-Harris EL, Lovley DR (1998) Microbiological evidence for Fe (III) reduction on early earth. Nature 395:65-67

Wang A, Haskin LA, Cortez E (1998) Prototype Raman spectroscopic sensor for in situ mineral characterization on planetary surfaces. Appl Spectrosc 52(4):477-487

Weber KA, Spanbauer TL, Wacey D, Kilburn MR, Loope DB, Kettler RM (2012) Biosignatures link microorganisms to iron mineralization in a paleoaquifer. Geology 40:747-750

Weiss JV, Emerson D, Megonigal JP (2004) Geochemical control of microbial Fe (III) reduction potential in wetlands: comparison of the rhizosphere to non-rhizosphere soil. FEMS Microbiol Ecol 48:89-100

Whitman WB, Coleman DC, Wiebe WJ (1998) Prokaryotes: the unseen majority. Proc Natl Acad Sci U S A 95: 6578-6583

Williams AJ, Sumner DY (2013) Development and preservation of filamentous mineral biosignatures: implications for detection with the Mars science laboratory. 44th Lunar and Planetary Science Conference, abstract 1741

Zachara JM, Fredrickson JK, Smith SC, Gassman PL (2001) Solubilization of Fe (III) oxide-bound trace metals by a dissimilatory Fe (III) reducing bacterium. Geochim Cosmochim Acta 65:75-93

Zhang G, Dong H, Jiang H, Kukkadapu RK, Kim J, Eberl D, Xu Z (2009) Biomineralization associated with microbial reduction of $\mathrm{Fe}^{3+}$ and oxidation of $\mathrm{Fe}^{2+}$ in solid minerals. Am Mineral 94:1049-1058

Zielinski RA, Bloch S, Walker TR (1986) Mobility and distribution of heavy metals during the formation of first cycle red beds. US Geol Bull 1578:51-59 